\title{
OPTIMIZATION OF A NEUTRON BEAM SHAPING ASSEMBLY DESIGN FOR BNCT AND ITS DOSIMETRY SIMULATION BASED ON MCNPX
}

\author{
I Made Ardana ${ }^{1}$, Yohannes Sardjono ${ }^{2}$ \\ ${ }^{1}$ Faculty of Mathematic and Natural Sciences, Gadjah Mada University, \\ Kompleks Bulaksumur, Sleman - DIY, 55281 \\ Email: i.made.ardana@mail.ugm.ac.id \\ ${ }^{2}$ Center for Accelerator Science and Technology - National Nuclear Energy Agency of Indonesia, \\ Jl. Babarsari, Sleman - DIY, 55281 \\ Diterima editor: 10 Juli 2017 \\ Diperbaiki: 27 Agustus 2017 \\ Disetujui untuk publikasi: 8 September 2017
}

\begin{abstract}
OPTIMIZATION OF A NEUTRON BEAM SHAPING ASSEMBLY DESIGN FOR BNCT AND ITS DOSIMETRY SIMULATION BASED ON MCNPX. This article involves two main objectives of BNCT system. The first goal includes optimization of $30 \mathrm{MeV}$ Cyclotron-based Boron Neutron Capture Therapy (BNCT) beam shaping assembly. The second goal is to calculate the neutron flux and dosimetry system of BNCT in the head and neck soft tissue sarcoma. A series of simulations has been carried out using a Monte Carlo N Particle X program to find out the final composition and configuration of a beam shaping assembly design to moderate the fast neutron flux, which is generated from the thick beryllium target. The final configuration of the beam shaping assembly design includes a $39 \mathrm{~cm}$ aluminum moderator, $8.2 \mathrm{~cm}$ of lithium fluoride as a fast neutron filter and a $0.5 \mathrm{~cm}$ boron carbide as a thermal neutron filter. Bismuth, lead fluoride, and lead were chosen as the aperture, reflector, and gamma shielding, respectively. Epithermal neutron fluxes in the suggested design were $2.83 \times 10^{9} \mathrm{n} / \mathrm{s} \mathrm{cm}^{-2}$, while other IAEA parameters for BNCT beam shaping assembly design have been satisfied. In the next step, its dosimetry for head and neck soft tissue sarcoma is simulated by varying the concentration of boron compounds in ORNL neck phantom model to obtain the optimal dosimetry results. MCNPX calculation showed that the optimal depth for thermal neutrons was $4.8 \mathrm{~cm}$ in tissue phantom with the maximum dose rate found in the GTV on each boron concentration variation. The irradiation time needed for this therapy were less than an hour for each level of boron concentration.
\end{abstract}

Keywords: Optimization, Beam Shaping Assembly, BNCT, Dosimetry, $30 \mathrm{MeV}$ Cyclotron, MCNPX.

\begin{abstract}
ABSTRAK
OPTIMASI DESAIN KOLIMATOR NEUTRON UNTUK SISTEM BNCT DAN UJI DOSIMETRINYA MENGGUNAKAN PROGRAM MCNPX. Telah dilakukan penelitian tentang sistem BNCT yang meliputi dua tahapan simulasi dengan menggunakan program MCNPX yaitu uji simulasi untuk optimasi desain kolimator neutron untuk sistem BNCT berbasis Siklotron $30 \mathrm{MeV}$ dan uji simulasi untuk menghitung fluks neutron dan dosimetri radiasi pada kanker sarkoma jaringan lunak pada leher dan kepala. Tujuan simulasi untuk mendapatkan desain kolimator yang paling optimal dalam memoderasi fluks neutron cepat yang dihasilkan dari sistem target berilium sehingga dapat dihasilkan fluks neutron yang sesuai untuk sistem BNCT. Uji optimasi dilakukan dengan cara memvariasikan bahan dan ketebalan masing-masing komponen dalam kolimator seperi reflektor, moderator, filter neutron cepat, filter neutron thermal, filter radiasi gamma dan lubang keluaran. Desain kolimator yang diperoleh dari hasil optimasi tersusun atas moderator berbahan Al dengan ketebalan $39 \mathrm{~cm}$, filter neutron cepat berbahan $\mathrm{LiF}_{2}$ setebal 8,2 cm, dan filter neutron thermal berbahan $B_{4} C$ setebal 0,5 cm. Untuk reflektor, filter radiasi gamma dan lubang keluaran masing-masing menggunakan bahan $\mathrm{PbF}_{2}, \mathrm{~Pb}$ dan Bi. Fluks neutron epithermal yang dihasilkan dari kolimator yang didesain adalah sebesar $2,83 \times 10^{9} \mathrm{n} / \mathrm{s} \mathrm{cm}^{-2}$ dan telah memenuhi seluruh parameter fluks neutron yang sesuai untuk sistem BNCT. Selanjutnya uji simulasi dosimetri pada kanker sarkoma jaringan lunak pada leher dan kepala dilakukan dengan cara memvariasikan konsentrasi senyawa boron pada model phantom leher manusia (ORNL). Selanjutnya model phantom tersebut diiradiasi dengan fluks neutron yang berasal dari kolimator yang telah didesain sebelumnya. Hasilnya, fluks neutron thermal mencapai nilai tertinggi pada kedalaman 4,8 cm di dalam model phantom leher ORNL dengan laju dosis tertinggi terletak pada area jaringan kanker. Untuk masing-masing variasi konsentrasi senyawa boron pada model phantom leher ORNL supaya dapat mematikan jaringan kanker, membutukan waktu iradiasi neutron kurang dari satu jam.

Kata kunci: Optimasi, Kolimator, BNCT, Dosimetri, Siklotron $30 \mathrm{MeV}, \mathrm{MCNPX}$
\end{abstract}

DOI: $\underline{10.17146 / \mathrm{tdm} \cdot 2017.19 .3 .3582}$ 


\section{INTRODUCTION}

Cancer begins when cells in a part of the body start to grow out of control. There are many kinds of cancer, but they all start due to the uncontrolled growth of abnormal cells. One type of cancer that can affect the human body is a soft tissue sarcoma. Soft-tissue sarcoma is rare, with an annual incidence around 5 per 100,000 [1]. Malignant fibrous histiocytoma, fibrosarcoma, angiosarcoma and malignant peripheral nerve sheath tumor are the most frequently found sarcoma types in the head and neck [2]. Soft tissue sarcomas account for the majority (80\%) of all sarcomas in the human body and constitute about $20 \%$ of all sarcomas affecting the head and neck regions in adults and approximately $35 \%$ in children. The face and neck are the most frequent sites affected in the head and neck region as shown in Figure 1 [3].

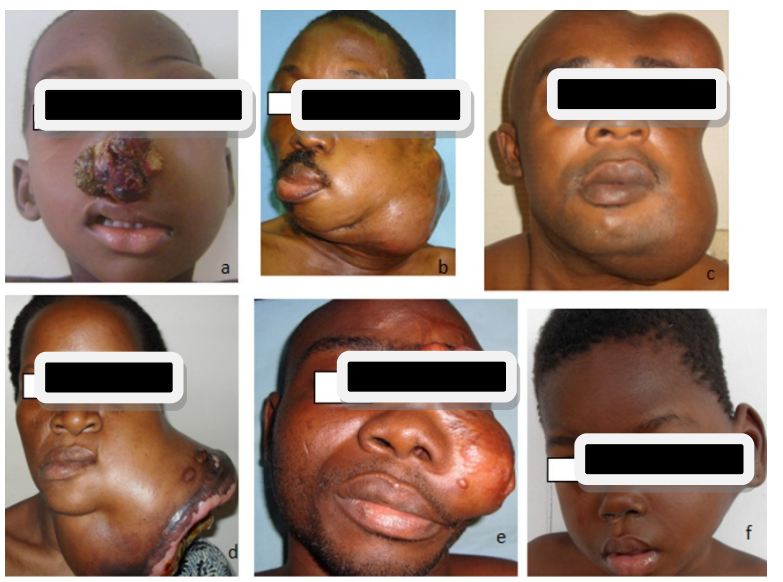

Figure 1. Clinical photographs of patients with soft tissue sarcoma [3]

A wide variety of therapeutic approaches is used in the management of these cancers. Traditionally, surgery has been considered to be the treatment of choice. Due to the high rate of recurrence of these tumors after surgery, radiotherapy and chemotherapy have recently been added as additional treatment strategies to improve disease control and prognosis [4]. Radiation therapy is followed after resection of all high-grade sarcomas and large tumors, and when margins of resection are closed or microscopically involved. Systemic chemotherapy is recommended for tumors with a significant risk of distant metastases [5]. However, cancer treatment with radiation and chemotherapy methods are also able to trigger other cancers in the body [1]. It is important to develop a new cancer therapy method that can be used to overcome some of the weaknesses of previous cancer therapy methods. Currently, a therapy has been developed that is expected to deal with soft tissue sarcoma. That cancer treatment method is known as Boron Neutron Capture Therapy (BNCT) [6].

Boron Neutron Capture Therapy (BNCT) has for many decades been advocated as an innovative form of radiotherapy that, in principle, has the potential to be the ideal form of treatment for many types of cancers [7]. BNCT is a particular kind of tumor treatment based on the possibility of selectively accumulating the isotope ${ }^{10} \mathrm{~B}$ in tumor tissue as shown in Figure 2 [8]. $\mathrm{BNCT}$ is a binary treatment modality that involves the selective accumulation of boron carriers in tumors followed by irradiation with a thermal or epithermal neutron beam. The high linear energy transfer (LET) $\alpha$ particles and recoiling ${ }^{7} \mathrm{Li}$ nuclei are emitted during the capture of thermal neutrons by the ${ }^{10} \mathrm{~B}$ nucleus. The high LET emitted particles deposit their energy in a range of about $10 \mu \mathrm{m}$, similar to a cell diameter. The fundamental BNCT reaction occurs close to the cell nucleus which increases the probability of DNA breaking, which leads to the death of cancer cells without damaging normal ones [9]. 


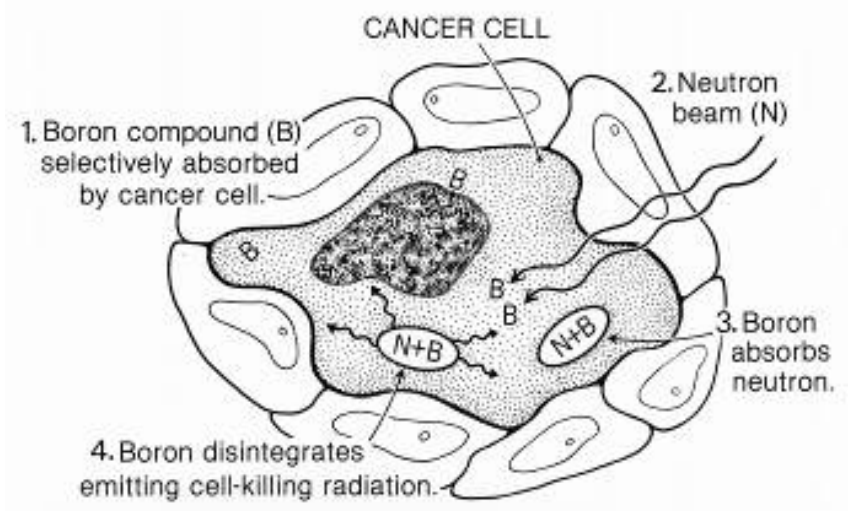

Figure 2. Neutron capture reaction in cancer cell (This image is in the public domain and can be freely reused)

Research about BNCT has also been carried out in Indonesia through a consortium of national research organization entitled Research and Technological Development and Application of Boron Neutron Cancer Therapy (BNCT) with Compact Neutron Generator. This consortium involves a number of institutions, like the National Atomic Energy Agency of Indonesia (BATAN), Ministry of Health, Kimia Farma Ltd., and a number of universities and hospitals [10]. This research is expected to enter preclinical trials in 2019/2020. Prior to the commencement of preclinical trial, studies of the BNCT system by simulations need to be conducted. The simulations could possibly include the neutron beam shaping assembly and its dose evaluation for some types of cancer $[6,11,12,13,14]$.

Head and neck soft tissue sarcoma is a type of cancer that is difficult to treat with surgical method. The delicate anatomy of the head and neck regions limits the ability to obtain wide surgical margins [2]. A new treatment method is required so that the mechanism for treating this type of cancer can be done without surgery. One such therapy method is BNCT. Before the therapy method can be applied in patients with sarcoma, simulations need to be conducted. Therefore, this study researched about the optimization of beam shaping assembly designs for BNCT based cyclotron $30 \mathrm{MeV}$ and its dosimetry simulation in the head and neck soft tissue sarcoma using Monte Carlo N Particle-X program.

\section{MATERIAL AND METHOD}

\section{Neutron Beam Shaping Assembly (BSA) Design}

BSA is a system tool that is used to produce the neutron fluxes corresponding to the fluxes of neutrons in BNCT therapy $[9,15]$. The neutron energy boundaries for the thermal, epithermal and fast neutron fluxes that are used in this simulation research were 0 to $0.5 \mathrm{keV}, 0.5 \mathrm{keV}$ to $40 \mathrm{keV}$, and $40 \mathrm{keV}$ to $30 \mathrm{MeV}$ respectively. Neutrons produced from a neutron source (accelerator, generator, and reactor) have the very high-energy (fast neutron). A moderation system is needed to produce the neutron flux corresponding to the fluxes of BNCT (epithermal neutrons). A BSA can be composed of several parts including the moderator, reflector, aperture, gamma shielding and thermal neutron filter $[9,16,17]$. A precise analysis of neutron transport through the beam shaping assembly has been performed by an MCNPX code on this research using 1 billion cycles. The general view of the beam shaping assembly configuration is shown in Figure 3. 


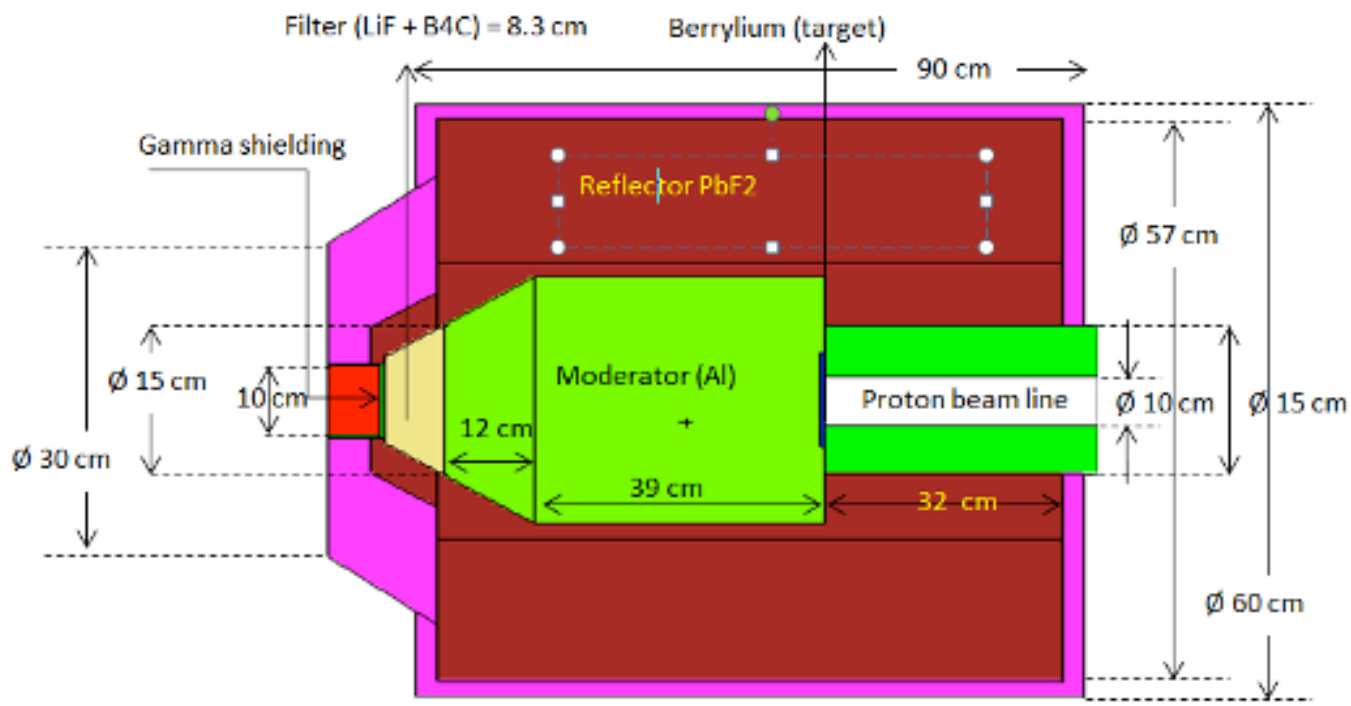

Figure 3. General view of the BSA configuration

Reflector, the best material for a reflector layer should have a high scattering cross-section where the fast neutrons can scatter all neutrons produced by the $\mathrm{Be}(\mathrm{p}, \mathrm{n}) \mathrm{B}$ reaction, back into the moderator layer in order to produce the epithermal neutrons. Suitable reflector materials are those with a high scattering cross-section and a high atomic mass (resulting in little energy loss). They include $\mathrm{Pb}, \mathrm{Bi}, \mathrm{PbF}_{2}$. These materials are varied in this study to find the best reflector material.

Moderator, a good moderator should have a high scattering cross-section for fast neutrons and a low absorption cross-section for epithermal neutrons. Another consideration is the selected appropriate materials, which require an appropriate mass number. A small mass number causes neutrons to moderate very quickly and thermal neutron contamination increases. On the other hand, if the mass number is large, neutrons cannot release a lot of their energy per collision. Moreover, in the BNCT, a moderator that contains a less radiative capture cross section (n, y), and less gamma emission in inelastic collisions is needed to avoid harmful gamma radiation to the patient. According to this, $\mathrm{MgF}_{2}, \mathrm{D}_{2} \mathrm{O}, \mathrm{CF}_{2}, \mathrm{Fe}, \mathrm{BeO}, \mathrm{AlF}_{3}$, Fluental $\left(69 \% \mathrm{AlF}_{3}, 30 \% \mathrm{Al}\right.$ and $\left.1 \% \mathrm{LiF}\right), \mathrm{Al}$ and $\mathrm{Al}_{2} \mathrm{O}_{3}$ were selected as various moderator materials. Various moderator thicknesses were simulated to determine the best moderator material.

Filter, a fast and thermal neutron filter has an important role in absorbing fast and thermal neutrons so that the neutron fluxes coming out of the beam shaping assembly are epithermal neutron fluxes only [18]. Filters in BSA are used to increase the ratio between the epithermal and thermal neutron flux and the ratio between the epithermal and fast neutron flux. This study varied $\mathrm{LiF}, \mathrm{Li}_{2} \mathrm{O}, \mathrm{Mg}, \mathrm{MgO}, \mathrm{SiC}$, and $\mathrm{CaF}_{2}$ as the filter materials.

Gamma shielding, this section serves to absorb the gamma rays in the beam shaping assembly, therefore the chosen materials must have a high density. Recommended materials for gamma shielding are $\mathrm{Pb}$ and $\mathrm{Bi}$. $\mathrm{Pb}$ has a greater attenuation coefficient than $\mathrm{Bi}$. Nevertheless, $\mathrm{Bi}$ can pass more epithermal neutrons than $\mathrm{Pb}[18]$.

Aperture, the beam shaping assembly is located at the end of the neutron beam exit. A conical shape of the aperture is created at the end to concentrate the radiation beam toward the target phantom [15]. The aperture beam shaping assembly should be able to reflect the epithermal neutron beam towards the BSA exiting window. The material used for the beam shaping assembly is typically lithium polyethylene [18].

\section{Dosimetry Simulation}

Radiation dosimetry can be defined as the study of various quantities and units of radiation doses. The doses are quantized and the results are viewed as radiation on various materials. Dosimetry depends on the energy of radiation and the constituent elements of the material. 
Radiation dosimetry can also be understood as a method which is used to determine the amount of radiation energy deposited in a material by direct and indirect ionization. A neutron, when crossing human tissue will interact with the body tissue elements. The type of neutron interactions that occur from those interactions depends on the atoms in the body tissue elements.

There are 4 main doses (called physical dose) that contribute to the treatment of BNCT: the boron dose from the boron neutron capture reaction, the proton dose from the nitrogen capture reaction, the neutron dose, and the gamma dose. The primary dose is Lithium-7 and alpha with 2.79 $\mathrm{MeV}(6.1 \%)$ and $2.31 \mathrm{MeV}(93.9 \%)$ of energy respectively. The Lithium-7 produced from the decay reaction will revert back to the initial energy level and will emit gamma radiation $(0.48 \mathrm{MeV})$. The average energy produced between the interactions of Boron-10 with thermal neutrons is $2.33 \mathrm{MeV}$.

The secondary dose comes from three interactions. The interaction between fast and thermal neutrons with tissue commonly called neutron scattering. The calculated dose is derived from neutrons scattering due to the reaction between fast and thermal neutrons with Hydrogen-1 nuclei. Protons are recoil products in this interaction. Gamma and hydrogen-2 are produced from the absorption reaction between the neutron interactions with hydrogen contained in body tissue. This produced hydrogen-2 is an excited atom. The production rate of hydrogen-2 from the thermal neutron interaction with hydrogen-1 is proportional to the photon release rate of $2.33 \mathrm{MeV}$ of energy. Nitrogen-14 has a fairly high mass fraction at $4.5 \%$ of the tissue mass. Irradiated tissue by thermal neutron leads to the interaction of thermal neutrons with nitrogen-14. This reaction produces carbon-14 and protons with $0.66 \mathrm{MeV}$ of energy. Carbon-14 is a radioactive element with a long half-life of 5730 years.

The weighted total dose (Dt) is defined as the sum of the physical dose components multiplied by the weighting-factors of each dose component in a tissue:

$$
\mathrm{Dt}=\mathrm{D} \gamma \cdot \mathrm{W} \gamma+\mathrm{Dn} \cdot \mathrm{Wn}+\mathrm{Dp} \cdot \mathrm{Wp}+\mathrm{Db} \cdot \mathrm{Wb}
$$

Where $\mathrm{D} \gamma$ is the gamma dose, $\mathrm{Dn}$ is the neutron dose, $\mathrm{Dp}$ is the nitrogen dose and $\mathrm{Db}$ is the boron dose. The weighting factor values for each dose components are given in Table 1. In order to calculate the absorbed dose at various positions, the neutron sources from the BNCT beam shaping assembly design were used. The calculated of gamma-ray dose, proton dose, boron dose and fast neutron absorbed dose were derived from the dose conversion coefficients. The calculations were conducted using F4 tally of MCNPX code combined with DE and DF factor as the value of the dose conversion coefficient for neutron, proton, gamma, and an alpha particle.

Table 1. Weighting factor values for each dose components [15].

\begin{tabular}{lll}
\hline Dose & Quality factor & Symbol \\
\hline Boron & 3.8 (cancer) & $W b$ \\
& 1.3 (healthy) & \\
Proton & 3.2 & $W p$ \\
Neutron & 3.2 & $W n$ \\
Gamma & 1 & $W \gamma$ \\
\hline
\end{tabular}

\section{RESULTS AND DISCUSSION}

\section{Beam Shaping Assembly Design}

Be was chosen as the target material on this study. ${ }^{9} \mathrm{Be}$ is able to produce the greatest neutron flux when compared to the neutron flux generated by other materials like ${ }^{7} \mathrm{Li},{ }^{181} \mathrm{Ta}$ and ${ }^{184} \mathrm{~W}$. Additionally, it has a higher melting and boiling point than ${ }^{7} \mathrm{Li}[19]$. Table 2 shows the target material characteristics for ${ }^{9} \mathrm{Be},{ }^{7} \mathrm{Li},{ }^{181} \mathrm{Ta}$ and ${ }^{184} \mathrm{~W}$. Calculations show that the beam shaping assembly design produces $1.33 \times 10^{11} \mathrm{n} / \mathrm{s} \mathrm{cm}^{-2}$ of total neutron fluxes on a $19 \mathrm{~cm}$ target diameter with a $0.5 \mathrm{~cm}$ thickness. The total neutron fluxes consist of $9.15 \times 10^{7} \mathrm{n} / \mathrm{s} \mathrm{cm}^{-2}$ of thermal neutron 
flux, $1.05 \times 10^{10} \mathrm{n} / \mathrm{s} \mathrm{cm}^{-2}$ of epithermal neutron flux, and $1.23 \times 10^{11} \mathrm{n} / \mathrm{s} \mathrm{cm}^{-2}$ of fast neutron flux. The total neutron flux will be moderated in the designed beam shaping assembly to produce a neutron flux which is suitable for BNCT system.

Table 2. Target material characteristics as neutron sources [19].

\begin{tabular}{cccccc}
\hline Target & $\begin{array}{c}\text { Melting point } \\
\left({ }^{0} \mathrm{C}\right)\end{array}$ & $\begin{array}{c}\text { Boiling point } \\
\left({ }^{0} \mathrm{C}\right)\end{array}$ & $\begin{array}{c}\text { Thermal } \\
\text { conductivity } \\
(\mathrm{W} / \mathrm{mK})\end{array}$ & $\begin{array}{c}\text { Neutron yield } \\
(\mathrm{n} / \mathrm{smA})\end{array}$ & $\begin{array}{c}\text { Gamma-ray } \\
\text { per one } \\
\text { neutron }\end{array}$ \\
\hline $\mathrm{Li}$ & 180 & 1340 & 84.7 & $1.14 \times 10^{14}$ & 0.09 \\
$\mathrm{Be}$ & 1278 & 2970 & 201 & $1.90 \times 10^{14}$ & 0.02 \\
$\mathrm{Ta}$ & 3017 & 5448 & 57.5 & $1.27 \times 10^{14}$ & 0.93 \\
$\mathrm{~W}$ & 3422 & 5555 & 174 & $9.65 \times 10^{14}$ & 1.40 \\
\hline
\end{tabular}

The neutron flux used for BNCT system is the epithermal neutron flux. To obtain the epithermal neutron flux, the total fluxes of neutron are moderated by various moderator materials in the beam shaping assembly design. The total neutron fluxes generated from the ${ }^{9} \mathrm{Be}(\mathrm{p}, \mathrm{n}){ }^{9} \mathrm{~B}$ reaction have various trajectories. So, a neutron reflector is needed to steer the neutron flux to the moderation room. Various materials were simulated as reflector materials in this study. The output is given in Figure 4. Based on Figure 4, $\mathrm{PbF}_{2}$ is the best material to be chosen as the reflector. Our criterion for choosing the best reflector material is based on each material's capability to reflect the greatest number of neutrons. In addition to the moderator and reflector, the beam shaping assembly design is also fitted with filters to reduce the fast neutron flux, thermal neutron flux, and its gamma contamination.

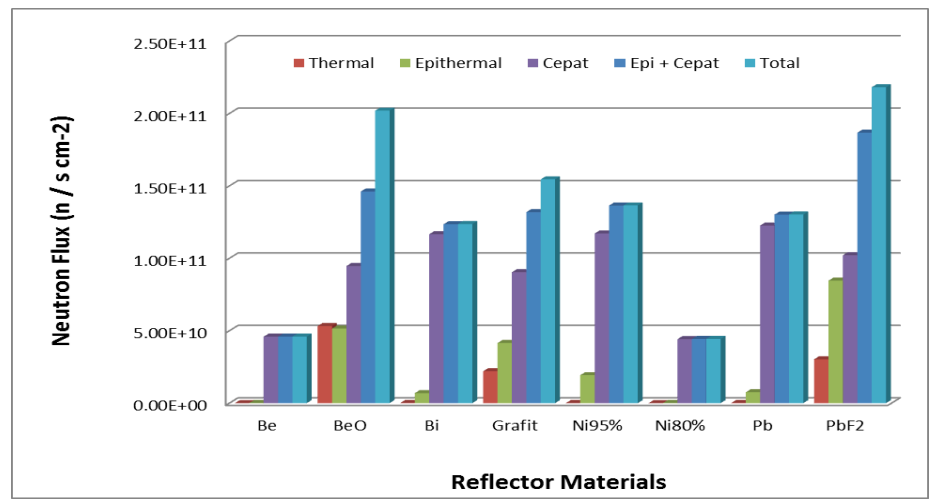

Figure 4. Results of various materials used as reflectors

Tally type $\mathrm{F} 4$ was used to obtain the thermal, epithermal, and fast neutron flux in the moderator layer. Various materials such as $\mathrm{Al}, \mathrm{Al}_{2} \mathrm{O}_{3}, \mathrm{AlF}_{3}, \mathrm{CaF}_{2}, \mathrm{Fe}, \mathrm{LiF}, \mathrm{MgF}_{2}, \mathrm{Ni}$, and $\mathrm{Pb}$ were simulated as moderator material. The results of the simulations are shown in Figure 5.

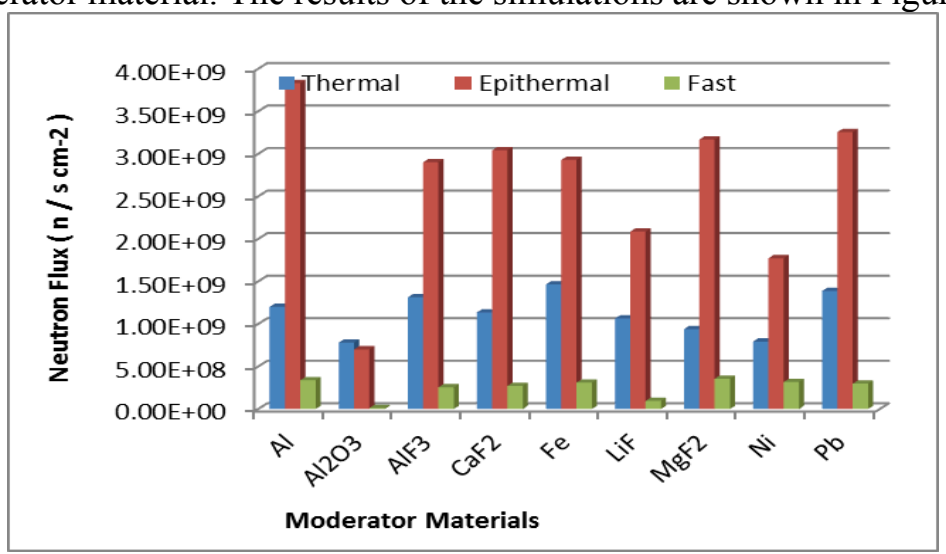

Figure 5. Thermal, epithermal, and fast neutron flux in the moderator layer 
According to the results shown in Figure 5, the best moderator material is aluminum. It generated the highest epithermal neutron flux with low fast neutron contamination. Therefore, aluminum was chosen as the moderator material in this study. The study was continued in several simulations to discover the optimal neutron filter and gamma shielding materials. $12 \mathrm{~cm} \mathrm{CaF}_{2}, 0.3$ $\mathrm{cm} \mathrm{B}_{4} \mathrm{C}$, and $0.5 \mathrm{~cm} \mathrm{~Pb}$ were chosen as the fast neutron filter, thermal neutron filter, and gamma shielding respectively. The beam shaping assembly design used in this simulation to determine the neutron flux which is suitable for BNCT system is shown in Figure 6. Table 3 shows the neutron flux characteristics as the output of the simulation calculation of the beam shaping assembly design. $\mathrm{Pb}$ material with $11 \mathrm{~cm}$ in diameter was chosen as the aperture parameter.

Table 3. Neutron flux characteristics as the output of the final calculations

\begin{tabular}{|c|c|c|c|}
\hline Parameters & Unit & Optimization results & IAEA standard \\
\hline Epithermal neutron flux & $\Phi_{\text {epi }}\left(n / \mathrm{sm}^{-2}\right)$ & $2.83 \times 10^{9}$ & $>1.0 \times 10^{9}$ \\
\hline $\begin{array}{c}\text { Fast neutron dose rate to } \\
\text { epithermal neutron flux } \\
\text { ratio }\end{array}$ & $\mathrm{D}_{\mathrm{f}} / \Phi_{\text {epi }}\left(G y-\mathrm{cm}^{2} / n\right)$ & $9.80 \times 10^{-14}$ & $<2.0 \times 10^{-13}$ \\
\hline $\begin{array}{c}\text { Gamma dose rate to } \\
\text { epithermal neutron flux } \\
\text { ratio }\end{array}$ & $\mathrm{D}_{\mathrm{y}} / \Phi_{\text {epi }}\left(G y-\mathrm{cm}^{2} / n\right)$ & $2.53 \times 10^{-14}$ & $<2.0 \times 10^{-13}$ \\
\hline $\begin{array}{c}\text { Thermal neutron to } \\
\text { epithermal neutron flux } \\
\text { ratio }\end{array}$ & $\Phi_{\text {th }} / \Phi_{\text {epi }}$ & 0.038 & $<0.05$ \\
\hline $\begin{array}{c}\text { Epithermal neutron } \\
\text { current to flux ratio }\end{array}$ & $\Phi_{\text {epi } / \mathrm{J}_{\text {epi }}}$ & 0.879 & $>0.7$ \\
\hline
\end{tabular}

\section{Dosimetry Simulation}

This study was started by simulating the ORNL neck phantom model using the MCNPX code. A cancerous tissue was then placed on the left side of the neck phantom model. The cancerous tissue is divided into three parts (Figure 6), namely the Planning Tumor Volume (PTV), Clinical Tumor Volume (CTV), and the Gross Tumor Volume (GTV). GTV is an area that is detected as the primary cancer site with the greatest density of cancer cells. The CTV is the GTV area coupled with the volume area around the GTV where suspected spreading of cancer cells occurred. PTV is a CTV area coupled with additional limits on the movement or deformation of cancer cells. The limitations of GTV, CTV, and PTV are determined by oncologists based on the biological characteristics of the cancer tissues [20].

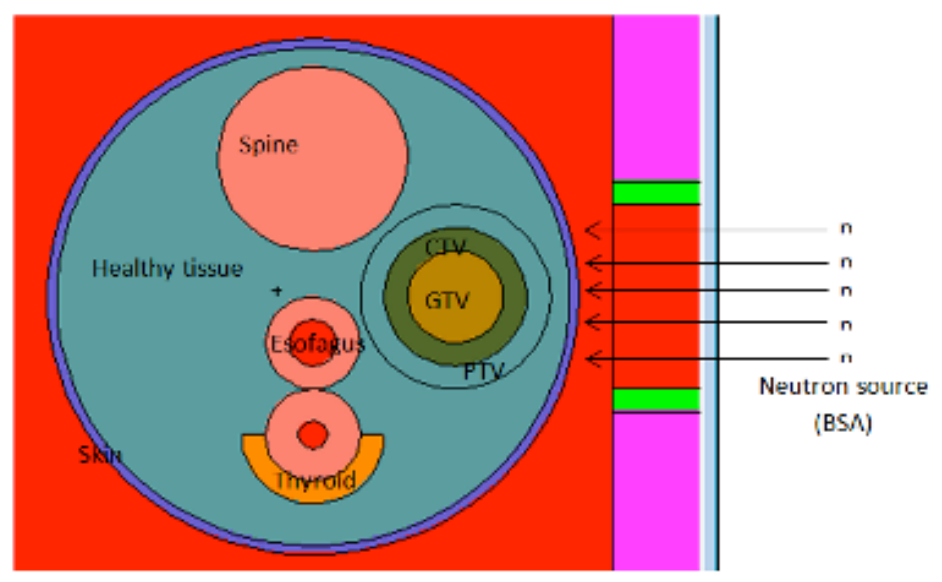

Figure 6. ORNL neck phantom model in the lateral view

The $2.83 \times 10{ }^{9} \mathrm{n} / \mathrm{s} \mathrm{cm}^{-2}$ of thermal neutron flux are pointed to irradiate the neck phantom model and then will passed through a moderation process in the neck phantom model tissues. The greater the depth of the neutron flux is transported in the tissue, the greater the thermal neutron flux 
will be produced. Figure 7 presents a graph of neutron flux characteristics when passed through the neck phantom model tissues. The number of thermal neutron flux is peaked at an approximate depth of 40 up to $60 \mathrm{~mm}$ from the surface of the skin. The amount of thermal and epithermal neutron flux is decreased on subsequent depths.

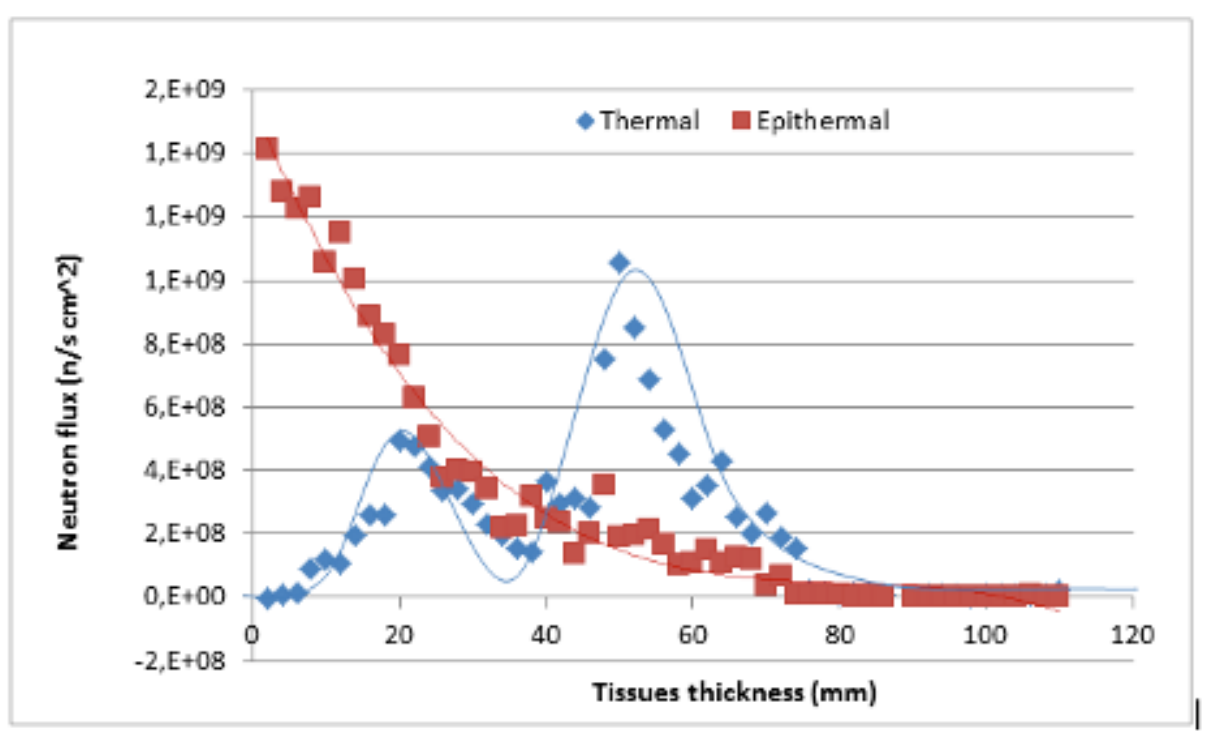

Figure 7. Neutron flux characteristics when passed through the neck phantom model tissues

The graph presented in Figure 8 shows the dose rate characteristics in each tissue in the neck phantom model. The highest value of the dose rate is found in the cancerous tissue (GTV). GTV contains the highest boron concentration for each dose rate variation simulation and it has a higher dose rate than other healthy tissue.

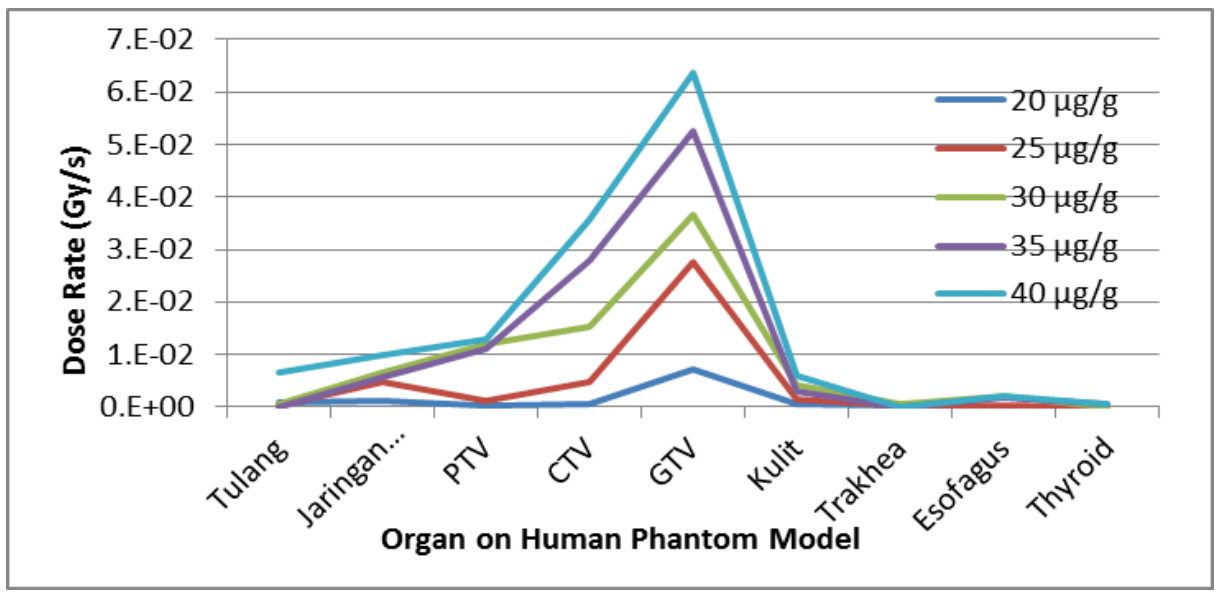

Figure 8. Dose rate characteristics in each tissue in the neck phantom model

The total weighted dose required to manage a pre-operative soft tissue sarcoma is $50 \mathrm{~Gy}$. In the BNCT treatment method, a neutron radiation system was planned in a single fraction. In a single fraction method, the radiation treatment will be carried out by a single radiation dose. Since the dose of radiation needed to kill the cancerous tissue must be large enough, it is necessary to calculate and determine the affects of dose on other tissues, such as skin and healthy tissues in the ORNL neck phantom model. The total dose is obtained by multiplying the radiation dose rate with the time needed to administer a 50 Gy total dose. Table 4 presents the time needed to deliver a 50 Gy total dose in cancer tissue. 
Table 4. Treatment time for each boron concentration variations in neck ORNL phantom model

\begin{tabular}{ccccc}
\hline $\begin{array}{c}\text { Boron } \\
\text { concentration }\end{array}$ & & Total Dose $(\mathrm{Gy})$ & & $\begin{array}{c}\text { Treatment } \\
\text { times }(\mathrm{t})\end{array}$ \\
\cline { 2 - 5 }$(\mu \mathrm{g} / \mathrm{g})$ & GTV & Healthy tissues & Skin & hour \\
20 & 50 & 10 & 6 & 2 \\
25 & 50 & 9 & 6 & 0.5 \\
30 & 50 & 8 & 4 & 0.4 \\
35 & 50 & 7 & 3 & 0.3 \\
40 & 50 & 6 & 3 & 0.2 \\
\hline
\end{tabular}

\section{CONCLUSION}

Two main objectives were investigated in this simulation study. First, this study aims to design a neutron BSA which is suitable for a BNCT system. The second goal is to calculate the neutron fluxes and dosimetry system of BNCT in the head and neck soft tissue sarcoma (STS). All simulations were performed using the MCNPX, a Monte Carlo radiation transport code for both the neutron beam shaping assembly design and dosimetry evaluations. The neutron BSA was designed to be used in treating a head and neck STS cancer to find out the BNCT irradiation time. The thermal neutron dose, including the boron and nitrogen doses, fast neutrons as well as photon doses have been investigated to find out the total dose of this treatment method. To perform these calculations, kerma investigations for all particles are included. Finally, the total dose and treatment time to treat a head and neck soft tissue sarcoma in the ORNL neck phantom model has been calculated.

\section{ACKNOWLEDGMENT}

We would like to thank all members who supported this project especially to the Center for Accelerator Science and Technology - National Nuclear Energy Agency of Indonesia (PSTABATAN) for the opportunities to perform this work.

\section{DAFTAR PUSTAKA}

1. Galy-Bernadoy, C. and Garrel, R., Head and neck soft-tissue sarcoma in adults. European Annals of Otorhinolaryngology, Head and Neck diseases. 2016. 133: 37-42.

2. Bree, R. D., Waal, V.D., Bree, E. D., and Leemans, C. R. Management of adult soft tissue sarcomas of the head and neck. Oral Oncology. 2010. 46 (11): 786-790.

3. Fasunla, A.J. and Daniel, A. Retrospective Review of Soft Tissue Sarcoma of Head and Neck in a West African Hospital. Alexandria Journal of Medicine. 2013. 49 (1): 43-48.

4. Aguino, Z.P., Vintro, X.L.Sancho, F.J., Pousa, L., dan Agusti, M.Q. Head and Neck Sarcomas. Our Experience. Acta Ottorinolaringologica Espanola. 2011.62 (6): 436-442.

5. Tejani, M.A., Galloway, T.J., Ridge, J.A., dan Mehren, M.V. Head and neck sarcomas: A comprehensive cancer center experience. Cancers. 2013. 5 (23): 890-900.

6. Andoh, T., Fujimoto, T. Sudo, T., Fujita, I., Imabori, M., Moritake, H., Sugimoto, T., dan Sakuma, Y. Boron neutron capture therapy for clear cell sarcoma ( CCS ): Biodistribution study of $\mathrm{p}$-borono- L -phenylalanine in CCS-bearing animal models. Applied Radiation and Isotopes. 2011. 69 (12): 1721-1724.

7. Moss, R.L. Critical review, with an optimistic outlook, on Boron Neutron Capture Therapy ( BNCT ). Applied Radiation and Isotopes. 2014.88 (1): 2-11. 
8. Gambarini, G. Dan Magni, D. Measurement of Gamma Dose and Thermal Neutron Fluence in Phantoms Exposed to a BNCT Epithermal Beam With TLD-700. Radiation Protection Dosimetry. 2014. 161 (1): 422-427.

9. Rasouli, F.S., Masoudi, S.F., dan Kasezas, Y. Design of a model for BSA to meet free beam parameters for BNCT based on multiplier system for D - T neutron source. Annals of Nuclear Energy. 2012. 39 (1): 18-25.

10. Anonim. PSTA-Batan Kembangkan Teknologi BNCT untuk sembuhkan Kanker. Biro Humas dan Protokol Provinsi Kalbar; 2014.

11. Tanaka, H., Sakurai, Y., Suzuki, M., Masunaga, S., Matsumoto, T., Fujita, K., Kashino, G., Kinashi, Y., Liu, Y., Takada, M., Ono, K., dan Marushasi, A. Experimental verification of beam characteristics for cyclotron-based epithermal neutron source (CBENS). Applied Radiation and Isotopes. 2011. 69 (12): 1642-1645.

12. Wang, Z., Morris, C.L., Bacon J.D., Brockwell, M.I., and Ramsey, J.C. A double helix neutron detector using micron-size $10 \mathrm{~B}$ powder, LANL; 2014.

13. Yonai, S., Itoga, T., Baba, M., Nakamura, T., Yokobori, H., and Tahara, Y. Benchmark experiments for a cyclotron-based neutron source for BNCT. Applied Radiation and Isotopes. 2009. 61 (1): 997-1001.

14. Capoulat, M.E., Herrera, M.S., Minsky, D.M., Gonzales, S.J. dan Kreiner A.J. Be (d,n) 10 B-based neutron sources for BNCT. Applied Radiation and Isotopes. 2014. 88(1): 190194.

15. Faghihi, F., dan Khalili, S. Beam Shaping Assembly of a D - T Neutron Source for BNCT and its Dosimetry Simulation in Deeply-seated Tumor. Radiation Physics and Chemistry. ., 2013. 89 (1): 1-13.

16. Burlon, A.A., Girola, S., Valda, A.A., Minsky, D.M., Kreiner, A.J., and Sanchez, G. Design of a beam shaping assembly and preliminary modeling of a treatment room for accelerator-based BNCT at CNEA. 2011. 69 (1): 1688-1691.

17. Pazirandeh, A., Torkamani, A., dan Taheri, A. Design and simulation of a neutron source based on an electron linear accelerator for BNCT of skin melanoma. Applied Radiation and Isotopes. 2011. 69 (5): 749-755.

18. International Atomic Energy and Agency. Current status of neutron capture therapy. Austria: IAEA; 2001.

19. Ono, K. Experience of BNCT by KUR and Start of Clinical BNCT Trial by Small Cyclotron Based Neutron Generator in KURRI. International Symposium The Application of Nuclear Technology to Support National Sustainable Development. Salatiga; 2015.

20. Joiner, M., and Van der Kogel, A. Basic Clinical Radiobiology, 4th ed. Great Britain: Hodder Arnold; 2009. 